\title{
Perception Assessment of the Impact of Human Activities on Stubbs Creek Forest Reserve, Akwa Ibom State, Nigeria
}

\author{
David Udoma-Michaels*, Benjamin Ndukwu, Andrew Obafemi \\ Institute of Natural Resources, University of Port Harcourt, Port Harcourt, Nigeria \\ Email: *davidudoma@yahoo.com
}

How to cite this paper: Udoma-Michaels, D., Ndukwu, B. and Obafemi, A. (2019) Perception Assessment of the Impact of Human Activities on Stubbs Creek Forest Reserve, Akwa Ibom State, Nigeria. Natural Resources, 10, 139-152.

https://doi.org/10.4236/nr.2019.105010

Received: April 15, 2019

Accepted: May 20, 2019

Published: May 23, 2019

Copyright $\odot 2019$ by author(s) and Scientific Research Publishing Inc. This work is licensed under the Creative Commons Attribution International License (CC BY 4.0).

http://creativecommons.org/licenses/by/4.0/

\begin{abstract}
Perception assessment of the impacts of human activities on Stubbs Creek Forest Reserve (SCFR) which is located between latitude $4^{\circ} 32^{\prime} \mathrm{N}$ and $4^{\circ} 40^{\prime} \mathrm{N}$ and longitude $7^{\circ} 48^{\prime} \mathrm{E}$ and $8^{\circ} 20^{\prime} \mathrm{E}$ (Figure 1) distributed into four Local Government Areas-Eket, Esit Eket, Ibeno and Mbo of Akwa Ibom State was carried out. Structural questionnaires to extract the common types of useful plants and animals, status of the protected area, derivable benefits and ways of preserving the SCFR were ministered to Chiefs Priests, Local Chiefs, Elderly People and Farmers who lived at least twenty years in the areas. Convenient sampling method was used to randomly select fifty respondents for the study. Descriptive statistics to summarize feedbacks from respondents presented in the form of tables, charts and histogram in line with the SCFR anthropogenic activities assessment indicators showing percentages and frequencies of such response was employed for data analyses and presentation. The results showed that the Stubbs Creek Forest Reserve have been disturbed and degraded due to uncontrolled human activities. Endangered fauna species including the Giraffa camelopardalis (Giraffe), Hippopotamus amphibious (Hippopotamus), Loxodonta africana (Elephant), Hynas, Kangaroo, Panther pardus (Leopard), Panther leo (Lion), Porcupine and Tiger were last seen between twenty and thirty five years ago in the forest while some useful plants of huge economic and medicinal values like Irvingia gabonensis (Bush mango) Tetrapleura itraptera, Gambeya albidum, Raphia hookeri (Rafia palm), Garcinia cola (Bitter kola) and Dacryodes edulis (Native pear) etc were last observed about eleven to twenty years ago. The study further revealed that Monkeys and Alligators are still very common in the Forest Reserve. It, therefore, recommends the strengthening and enforcement of regulatory controls on the use of SCFR by relevant authorities and alternative source of
\end{abstract}


firewood to reduce anthropogenic abuses and protect the rich resources of the forest from extinction.

\section{Keywords}

Perception, Stubbs Creek, Forest Reserve, Human Activities, Endangered

\section{Introduction}

Akwa Ibom State where SCFR is located lies within Latitudes $4^{\circ} 32^{\prime} \mathrm{N}, 5^{\circ} 33^{\prime} \mathrm{N}$ and Longitudes $7^{\circ} 25^{\prime} \mathrm{E}, 8^{\circ} 25^{\prime} \mathrm{E}$ of the equator and endowed with rich forests resources which her people exploit for varying purposes. The value of forest and forest products widely used for traditional, ecological, environmental, economic and medicinal purposes to mankind is vastly documented in many kinds of literature by different authors [1]-[6].

Human activities which involve clearing of vegetation for farming, logging, bush burning, petroleum exploitation and associated oil spill pollution, road construction, urbanization and industrialization have continued to cause forest depletion, and are always impacting negatively on forests resources [7] [8]. Unfortunately, SCFR - The study area which has been the largest forest reserve not only in Akwa Ibom State but the entire Eastern part of Nigeria with original size of $310.80 \mathrm{~km}^{2}$ in 1930 , have reduced significantly due to these anthropogenic activities [9] [10]. Recent study carried out to identify, classify and evaluate the land cover status of the reserve using the Remote Sensing technologies showed that there are two fundamental vegetation covers namely; the dense vegetation cover and sparse vegetation cover while the remaining land covers in the area are simply baresoil and water body [10]. Between 1993 and 2003, the dense vegetation cover had decreased from $63.50 \mathrm{~km}^{2}$ to $42.43 \mathrm{~km}^{2}$ and between 2003 and 2013; it decreased further to $28.22 \mathrm{~km}^{2}$ whereas the sparse land cover, bare soil and water body on the contrary, experienced significant increase in land cover classes in the study area within the same period. The study further projected the total disappearance of SCFR by the year 2033 if the observed trend of the Reserve's degradation as a result of the increasing rate of anthropogenic activities is not halted to reduce the huge loss of biological diversity and other resources in the Protected Area.

Records have shown that sufficient information to ascertain the current status of the presence of endangered species found in the forest considering the continuous depletion of the coverage area of the SCFR as a result of anthropogenic activities as reported is not available. Therefore this study seeks to assess the impacts of human activities on endangered species of the Protected Area as well as find ways of halting such degradable trend vis-à-vis the important role SCFR play both to man and the environment in line with vision 2030 Sustainable Development Goal objectives [11]. 


\section{Materials and Methods}

\subsection{Description of the Study Area}

The Stubbs Creek Forest Reserve (SCFR) in Akwa Ibom State which can be found between latitude $4^{\circ} 32^{\prime} \mathrm{N}$ and $4^{\circ} 44^{\prime} \mathrm{N}$ and longitude $7^{\circ} 48^{\prime} \mathrm{E}$ and $8^{\circ} 20^{\prime} \mathrm{E}$ cut across four Local Government Areas which are: Eket, Esit Eket, Ibeno and Mbo (Figure 1). It features three major vegetation types namely, the Mangrove swamp forest, Freshwater swamp and Tropical rainforest vegetation with various plant and animal species making it one of the major biodiversity hotspots within the Gulf Of Guinea [12]. The total annual rainfall of SCFR ranges from $1700 \mathrm{~mm}$ to $4700 \mathrm{~mm}$ and mean monthly temperature of $25^{\circ} \mathrm{C}$ to $28^{\circ} \mathrm{C}$ with well-drained or poorly drained soil thereby making agriculture the main occupation of the

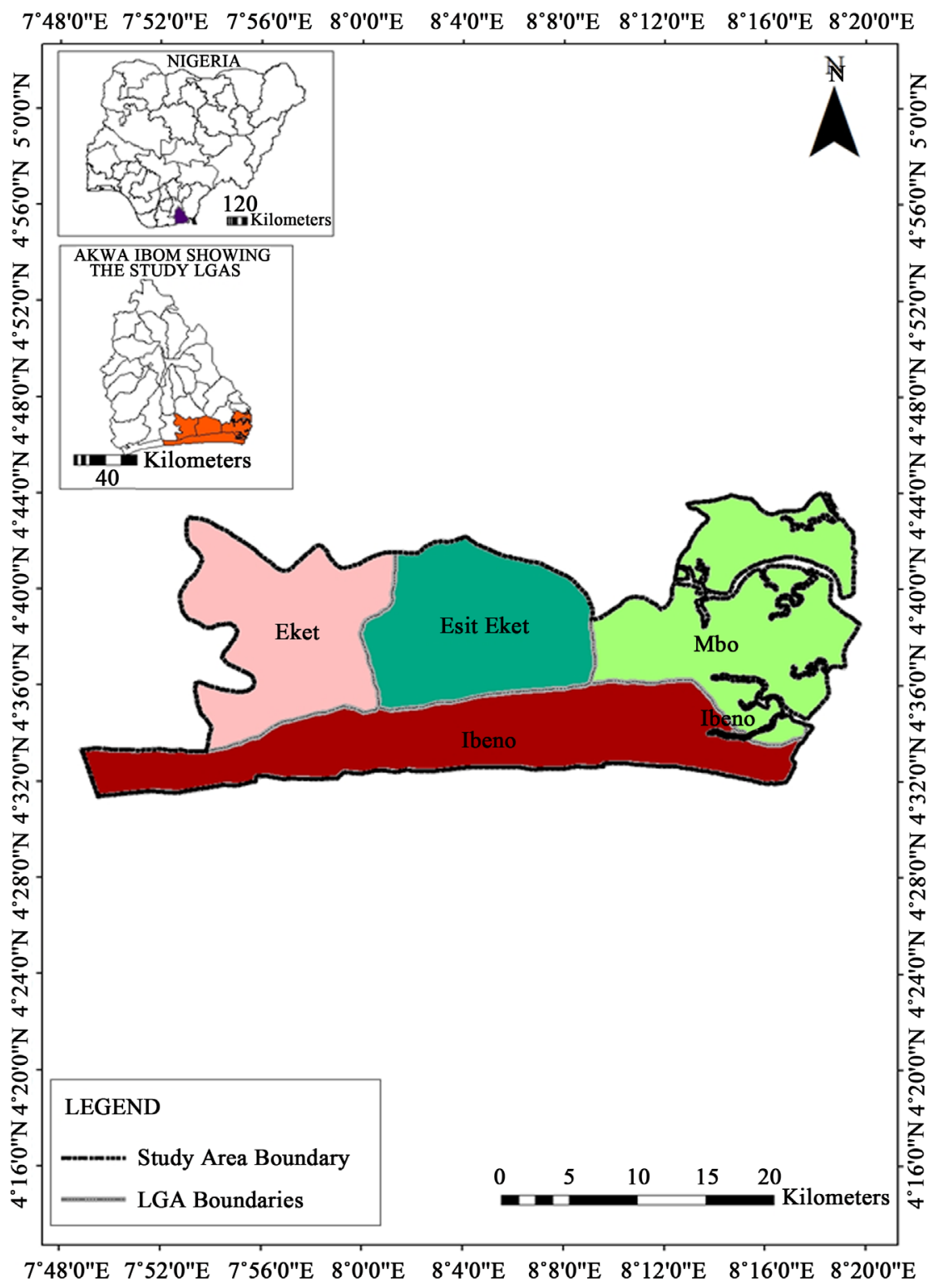

Figure 1. Study area. 
people [13]. It is difficult to see any civil servant from the study area without involved in part-time farming. In this way, it might be truly right to state that over $90 \%$ of Akwa people, as well as inhabitants, are engaged with agriculture. The SCFR likewise is luxuriously supplied with remarkable Oil and Gas reserves and play host to some global organizations like the Universal Energy Resources Ltd., the administrator of the Stubbs Creek Marginal Field, Frontier Oil Limited-Administrator of Uquo Marginal Field and Network E\&P, the administrator of Qua Iboe Marginal Field. These fields situated within the SCFR were all homestead-out to the recipients in 2003 [14]. All the three companies have since started exploration and production activities as required. It is reported from research that apart from direct destruction of the vegetation to facilitate construction of facilities, such activities may also cause severe consequences to the environment through the discharge of hydrocarbon and related constituents into the SCFR ecosystem [15].

\subsection{Data Gathering and Sampling Procedure}

The sampling technique employed for the study was the cross-sectional research design which endeavors to collect information from respondents across the population at a specific time in the study area. The study was carried out between May and July 2018. The study was designed to elicit information from the local people of the area (communities found within the Stubbs Creek Forest Reserve) among the sampled local government areas (LGAs) which include Eket, Esit-Eket, Ibeno and Mbo. Both primary and secondary data collection process were employed for the study. The primary data collection involved the use of questionnaire surveys designed for collecting first hand information from respondents. The communities selected for questionnaire survey were Afaha-Eket (Eket), Ekpene Obo (Esit-Eket), Upenekang (Ibeno) and Ewang (Mbo). These communities were selected because the Stubbs creek protected forest reserve links and extension cut across their LGAs boundaries. According to [16], the population figures for the LGAs are 172856, 63358, 74840 and 102173 persons for Eket, Esit-Eket, Ibeno and Mbo respectively. However, due to insufficient data on the individual population figures for sampled communities, convenient sampling method was employed to randomly select 50 respondents for perception studies (at least 12 respondents per selected community) based on their community status like chief priest, titled man (village chiefs) and natives (who have lived for at least 20 years in the community) of the communities. Purposive Sampling Technique was used to select the communities for questionnaire survey while the participants were randomly selected based on the availability of respondents belonging to these categories as indicated above. The questionnaire featured both closed and open-ended questions and was divided into two sections A and B; section A was on personal data of respondents while section B was on common plants types and forest reserve status. All questionnaires were answered and returned the same day during the field visit to ensure maximum return rate of $100 \%$. 


\subsection{Data Analysis}

A descriptive statistical tool of percentages and frequencies was used to summarize feedbacks from the respondents across the affected communities within the SCFR environment. Questionnaire samples returned were coded, recorded in excel worksheet 2007 and imported into the Statistical Package for Social Scientist (SPSS) 24.0 version for effective data analysis and presentation.

\section{Results and Discussions}

\section{Socio-Economic Characteristics of Respondents}

The gender ratio for sampled respondents showed that the total number of sampled males were $74 \%$ while the remaining $26 \%$ were females. The age ratio of sampled respondents uncovered that $14 \%$ of sampled respondents were between the age proportion of 31 - 40 years, $28 \%$ of the respondents were between 41 - 50 years while the remaining $58 \%$ of examined respondents were either 51 years of age or were over 51 years of age in the study area. The dimension of education among sampled respondents for the investigation demonstrated that $26 \%$ of the respondents had secondary level training, $70 \%$ of respondents had primary education, while the remaining $4 \%$ of sampled respondents have tertiary level of education in the study area. The conjugal status of respondents for the investigation uncovered that $88 \%$ of the respondents were married, $6 \%$ of respondents have been separated from their relational unions while $6 \%$ of the rest of the respondents are widowed. The class of occupation of respondents for the study uncovered that $20 \%$ of sampled respondents were government workers, $20 \%$ of respondents are into trading, artisanship recorded $16 \%$ of the respondents, and respondents who are into farming were $34 \%$, while the outstanding $10 \%$ of the respondents were into other occupational types like native medicines and transporters. The information for the average monthly income of sampled respondents revealed that $2 \%$ of respondents earn between 0 and $\# 25,000,34 \%$ of respondents earn between $\# 26,000$ and $\# 50,000,58 \%$ of respondents earn between $\# 51,000$ and $\# 100,000$, while the remaining $6 \%$ of respondents earn between $\# 101,000$ and \#150,000 respectively. The findings on the community status of sampled respondents revealed that $6 \%$ of respondents are community chief priest, $74 \%$ of respondents were native of the land, while the remaining $20 \%$ of respondents have one community title or the other. The information for the number of years lived in sampled communities by respondents revealed that $10 \%$ have lived in their community between 21 - 30 years; $20 \%$ of respondents have lived between 31 - 40 years; $30 \%$ of respondents have lived between $41-50$ years; while the remaining majority $(40 \%)$ of respondents have lived for at least 51 years and above (Table 1 ).

\section{State of Forest Reserve among Sampled Respondents}

The state of protected forests reserve revealed that $20 \%$ of the total number of respondents were not sure that the SCFR has been degraded or disturbed, $2 \%$ of respondents believed that the forest reserve from their perspective are 
Table 1. Socio-economic characteristics of sampled respondents.

\begin{tabular}{|c|c|c|}
\hline Characteristics & Frequency & Percentage \\
\hline \multicolumn{3}{|l|}{ Gender } \\
\hline Male & 37 & 74.0 \\
\hline Female & 13 & 26.0 \\
\hline \multicolumn{3}{|l|}{ Age } \\
\hline $31-40$ years & 7 & 14.0 \\
\hline $41-50$ years & 14 & 28.0 \\
\hline 51 years and above & 29 & 58.0 \\
\hline \multicolumn{3}{|l|}{ Level of Education } \\
\hline Primary & 13 & 26.0 \\
\hline Secondary & 35 & 70.0 \\
\hline Tertiary & 2 & 4.0 \\
\hline \multicolumn{3}{|l|}{ Marital Status } \\
\hline Married & 44 & 88.0 \\
\hline Separated & 3 & 6.0 \\
\hline Widow & 3 & 6.0 \\
\hline \multicolumn{3}{|l|}{ Occupation } \\
\hline Civil servant & 10 & 20.0 \\
\hline Trading & 10 & 20.0 \\
\hline Artisan & 8 & 16.0 \\
\hline Farmer & 17 & 34.0 \\
\hline Others & 5 & 10.0 \\
\hline \multicolumn{3}{|l|}{ Monthly Income } \\
\hline $0-\# 25,000$ & 1 & 2.0 \\
\hline$\# 26,000$ - \#50,000 & 17 & 34.0 \\
\hline$\# 51,000$ - \#100,000 & 29 & 58.0 \\
\hline$\# 101,000$ - \#150,000 & 3 & 6.0 \\
\hline \multicolumn{3}{|l|}{ Community Status } \\
\hline Chief Priest & 3 & 6.0 \\
\hline Native & 37 & 74.0 \\
\hline Titled man & 10 & 20.0 \\
\hline \multicolumn{3}{|c|}{ No. of Years Lived in Community } \\
\hline $21-30$ years & 5 & 10.0 \\
\hline $31-40$ years & 10 & 20.0 \\
\hline $41-50$ years & 15 & 30.0 \\
\hline 51 years and above & 20 & 40.0 \\
\hline
\end{tabular}


undisturbed; $14 \%$ of respondents believed that the forests are relatively disturbed; while the remaining $64 \%$ of respondents ( 32 in number) were of the opinion that the forest reserve has been disturbed and degraded (Figure 2).

\section{Perception on the Common Types of Plants That Existed in Forest Reserve}

The list of common plants types found in the forest reserve as explained by sampled respondents was displayed on (Table 2). The direct values and uses of these plant types are of socio-economic importance to the people, thus, its benefits to the local people cannot be over-emphasized.

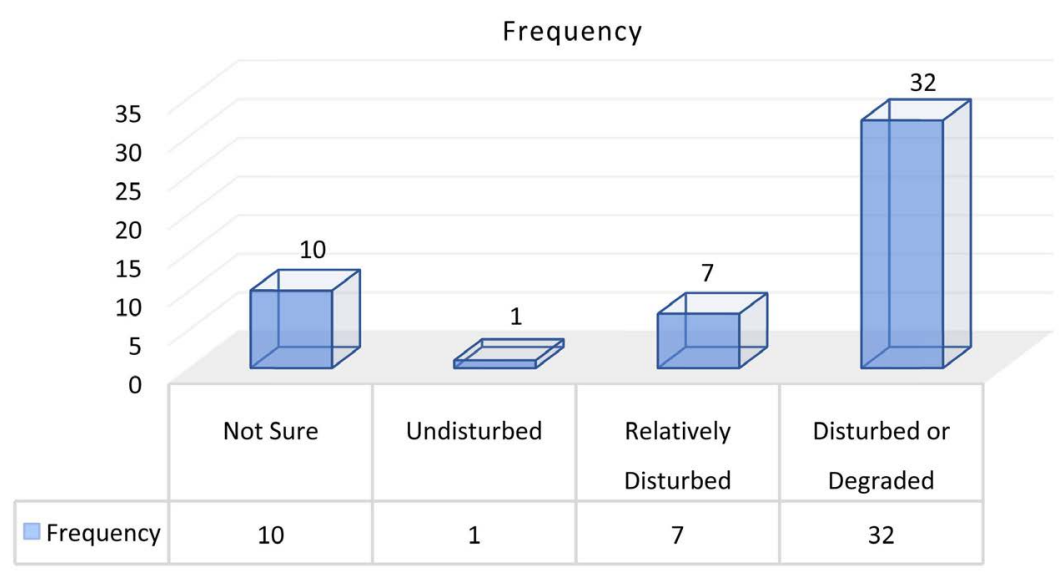

Figure 2. State of forest reserve in the study area.

Table 2. Some of the common plant types that existed in the study area.

\begin{tabular}{|c|c|c|c|}
\hline \multirow[b]{2}{*}{$\mathrm{S} / \mathrm{N}$} & \multicolumn{2}{|c|}{ Plant Types } & \multirow[b]{2}{*}{ Economic Value and Uses } \\
\hline & $\begin{array}{c}\text { Local Name } \\
\text { (Ibibio/Annang) }\end{array}$ & Scientific Name & \\
\hline 1 & Afang & Gnetum africanum & Used for soup like Afang and Ukwuoho \\
\hline 2 & Ayurveda & Taxus breviflora & Anti-Tumour drug \\
\hline 3 & Eben & Dacryodes edulis & Edible with maize \\
\hline 4 & Editan & Lasianthera africana & Food, vegetable source \\
\hline 5 & Efiad & Garcinia cola & Entertainment and cough treatment \\
\hline 6 & Eyop & Elaeis guineensis & Used for cooking, soap and margarine \\
\hline 7 & Isip-Mbakara & Cocos nucifera & $\begin{array}{l}\text { Oral rehydration therapy } \\
\text { and vitamin supplement }\end{array}$ \\
\hline 8 & Maprounnea & Papaver somniferum & Hypertension treatment \\
\hline 9 & Nsukakara & Spondias mombin & Edible fruit and foliage \\
\hline 10 & Udara & Gambeya albidum & Edible fruit and trunk for timber \\
\hline 11 & Ukod & Raphia hookeri & Palm wine for social events \\
\hline 12 & Unani & Artemisia annua & Anti-malaria \\
\hline 13 & Uyayak & Tetrapleura itraptera & $\begin{array}{c}\text { Used for pepper soup } \\
\text { especially for nursing mothers }\end{array}$ \\
\hline 14 & Uyo-Ikot & Irvingia gabonensis & Edible fruits and seed for soup \\
\hline
\end{tabular}




\section{Perception on the Last Time Plants That Are No Longer in Existence Were Noticed among Sampled Respondents}

The information for those plants not in existence and when they were last seen was obtained from sampled respondents. It was revealed that $8 \%$ of respondents were undecided, $16.0 \%$ of sampled respondent declared that some of these plants were last seen between 1 to 10 years; $40.0 \%$ of respondents believed that they were last seen about 11 years to 20 years ago (this means that more of the economic plants disappeared between year 2000 and year 2017); the remaining $36.0 \%$ of respondents believed that they were last seen about 21 years and 30 years. Thus, more of these common plants disappeared from 11 to 20 years ago (Figure 3).

\section{Status of Some Animals That Existed/Existing in the Forest Reserve}

The lists for some of the animals that still exist were identified against the extinct ones (Table 3). The information obtained revealed that certain animals are no longer seen and were last seen about 15 years to 20 years ago. Several types of encroachments were identified as the reason for their disappearance.

\section{Economic Value and Importance of Extinct Plants}

The information for the economic value and importance of plant that have faced extinction was obtained from sampled respondents. The information revealed that $46 \%$ of the respondents highlighted the plants ethno-medicinal value; $10 \%$ of the respondents believed in its forest wood value; $16 \%$ of the respondents declared on its direct uses as a source of income; while the remaining $28 \%$ of the respondents believed on its consumption value as food source (Figure 4).

\section{Change in Forest Size}

The forest sizes in the study area are gradually decreasing because the majority of sampled respondents (96\%) declared it. However, in some areas, it was observed by $2 \%$ of the respondents that the size of the forests was relatively stable. The last $2 \%$ of the respondents were not sure about the size if it is reducing or increasing in size (Figure 5).

Factors Responsible for the Current Size of Forests in the Study Area

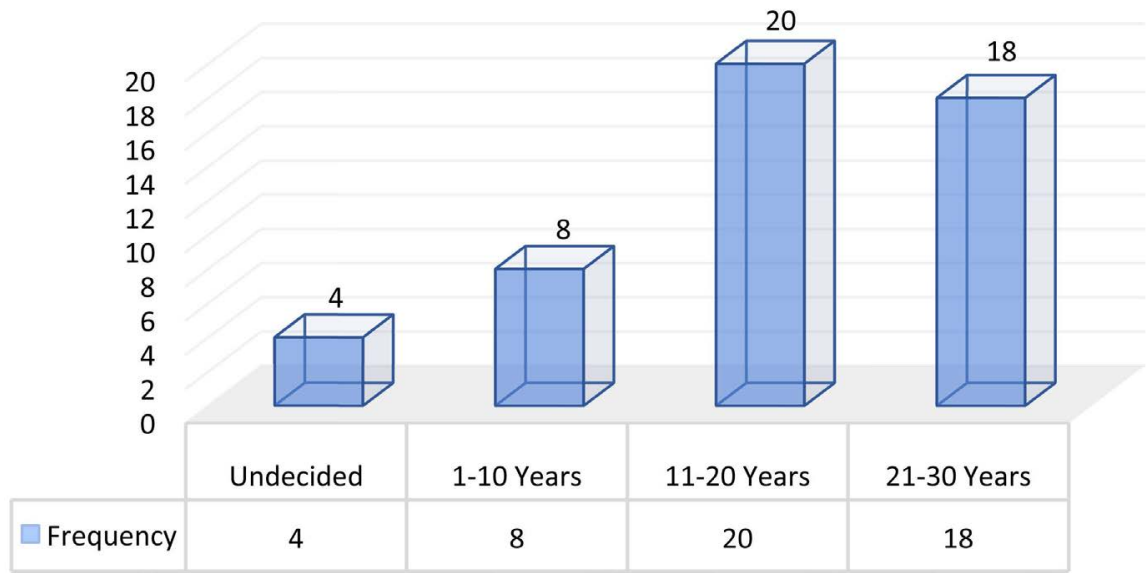

Figure 3. When did the disappeared plants last seen? 


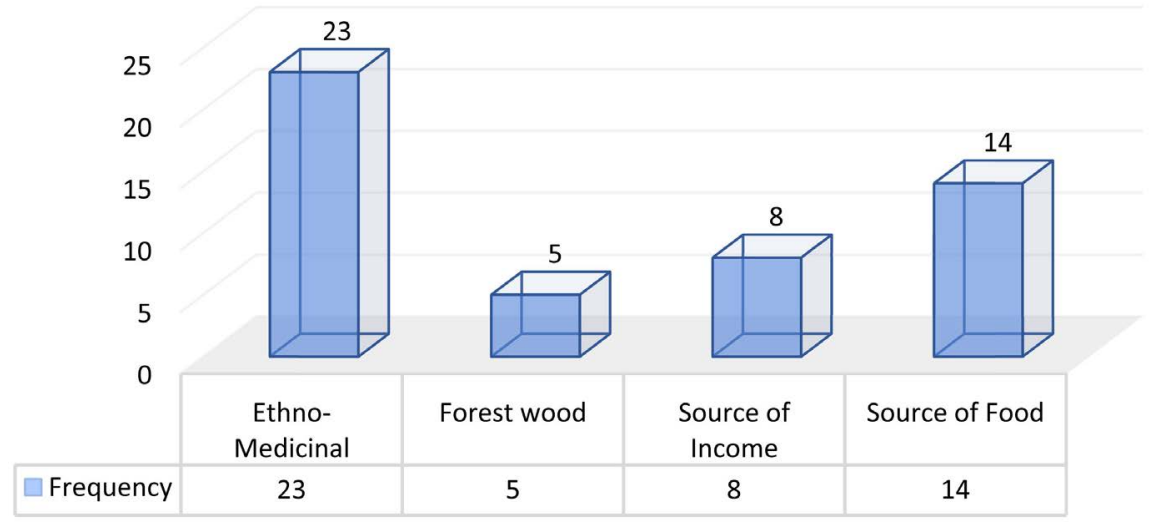

Figure 4. Economic value and importance of extinct plants.

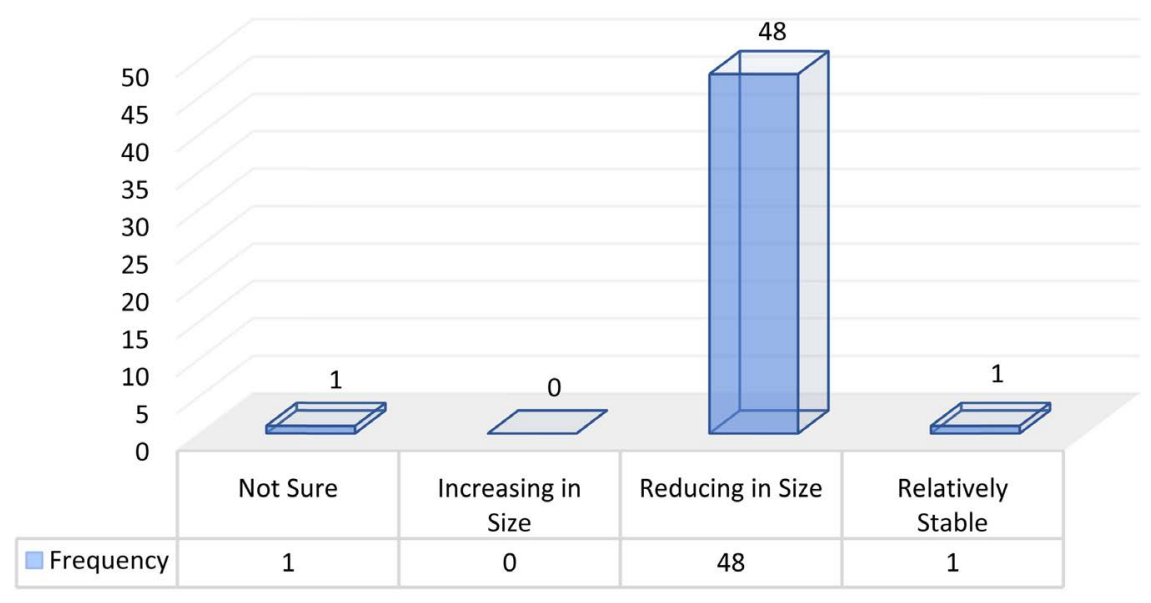

Figure 5. Is the size of the Forest Increasing or Decreasing?

Table 3. Status of animals that existed/existing in the area.

\begin{tabular}{ccccc}
\hline Animal Types & Extinct & $\begin{array}{c}\text { Last time seen/ } \\
\text { observed (Years) }\end{array}$ & $\begin{array}{c}\text { Not } \\
\text { extinct }\end{array}$ & $\begin{array}{c}\text { Last time seen/ } \\
\text { observed (Years) }\end{array}$ \\
\hline Alligators & No & - & Yes & 8 \\
Deer & Yes & 35 & - & - \\
Elephant & Yes & 30 & - & - \\
Giraffes & Yes & 35 & - & - \\
Hippopotamus & Yes & 30 & - & - \\
Hyenas & Yes & 30 & - & - \\
Kangaroo & Yes & 32 & - & - \\
Leopard & Yes & 25 & - & - \\
Lion & Yes & 30 & - & 5 \\
Monkeys & No & - & Yes & - \\
Porcupine & Yes & 20 & - & 3 \\
Snakes & No & - & Yes & Almost all day \\
Squirrels & No & - & Yes & - \\
Tiger & Yes & 30 & - & \\
(Python, Cobra and Others) & & & & \\
\hline
\end{tabular}

Note: Most frequent number of years indicated among sampled respondents were used. 
The factors responsible for the current size of forests are listed as: encroachment for settlement (82\%), overgrazing (58\%), fire incident $2 \%$, and others (20\%) like farming activities, oil production facilities for example (Universal Energy Resources Ltd and Mobil Producing Nigeria Unlimited), logging activities, and some sections fishing activities (Figure 6).

\section{Benefits Derivable from the Forests}

The benefits derivable from the forests as in (Figure 7) below includes: provision of food for domestic needs (80\%), high medicinal value (98\%), tourism (94\%), source of income (76\%), source of firewood from timber (30\%) and others (98\%) which includes protection of flooding, erosion and environmental sanitation (air purification).

\section{Do You Think the Forests Should Be Preserved?}

The perception of forest protection was examined among sampled respondents. It was revealed that $90 \%$ of the respondents were of the opinion that the forest should be protected; while the remaining $10 \%$ of the respondents were either not sure $(6.0 \%)$ of their decision or do not want $(4.0 \%)$ the protection of these forests (Figure 8).

\section{Suggested Ways of Protecting the Stubbs Creek Forest Reserve}

The ways of protecting the forested areas were examined among sampled respondents for the study. The result obtained showed that $78 \%$ of respondents indicated enactment and enforcement of laws; $62 \%$ indicated preservation of native laws. In addition, while $42 \%$ of respondents indicated to avoid encroachment by building fences/buffers around protected areas; $28 \%$ respondents said to avoid bush burning while $100 \%$ of respondents indicated to promote other alternative sources of firewood like cooking gas and stoves; $96 \%$ of the respondents highlighted other options like creation of more protected lands/areas, promote less cultivation of lands and ensure the planting of more trees (Figure 9).

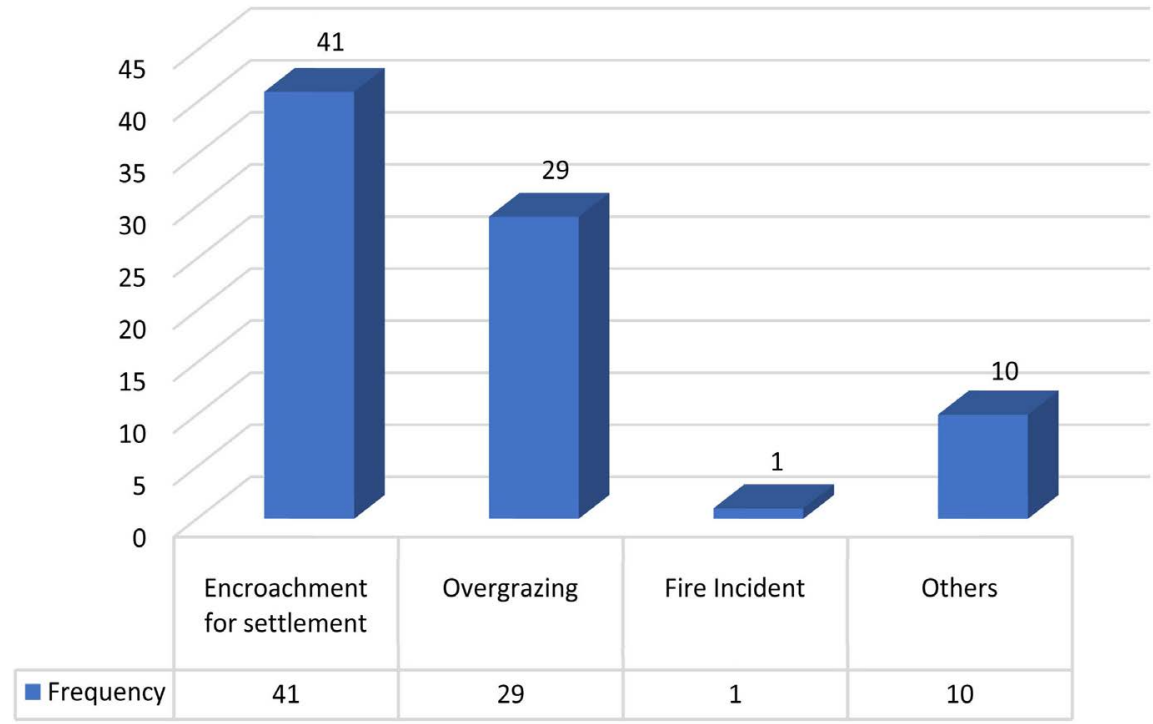

Figure 6. Factors responsible for the current size of forests in the study area. 


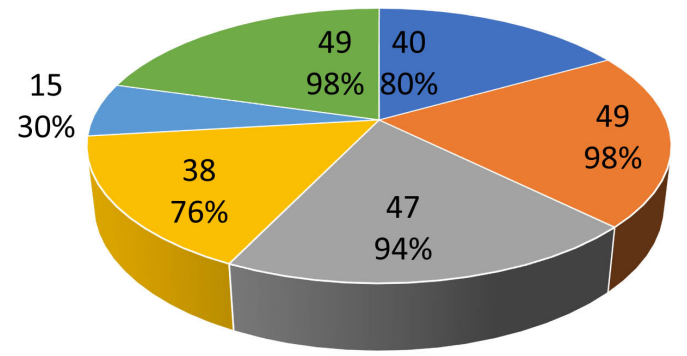

- Provision of food for domestic needs - High Medicinal value

- Tourism

- Source of Income

- Source of Firewood/Timber

- Others

Figure 7. Benefits derivable from the forests.

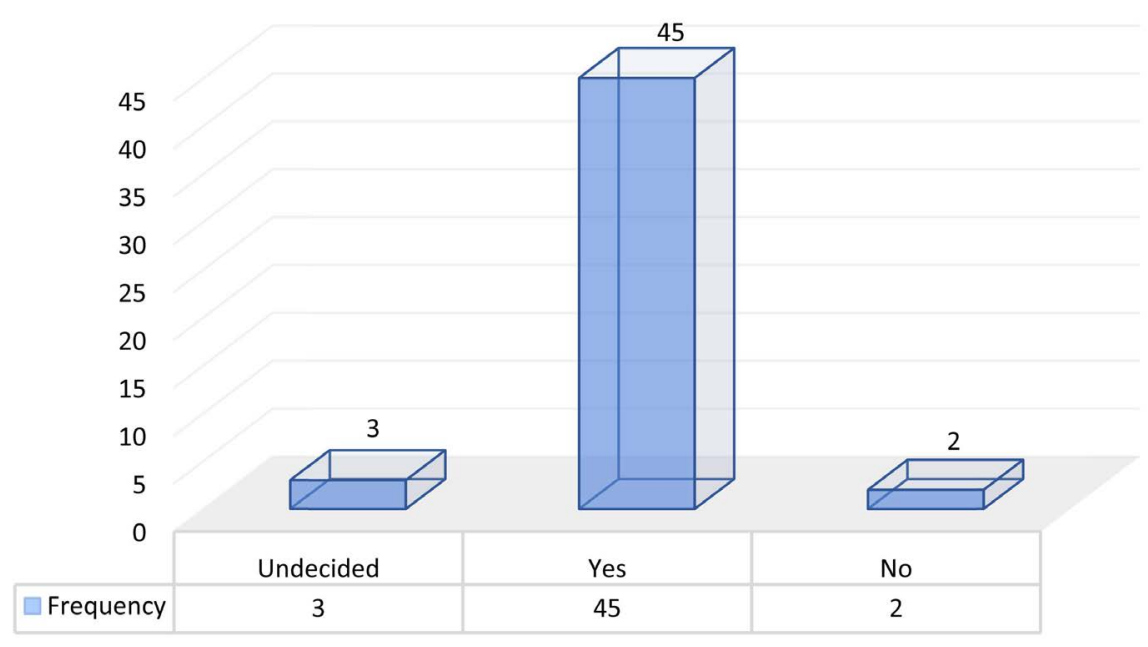

Figure 8. Sampled opinions of respondents on whether or not to preserve the forest

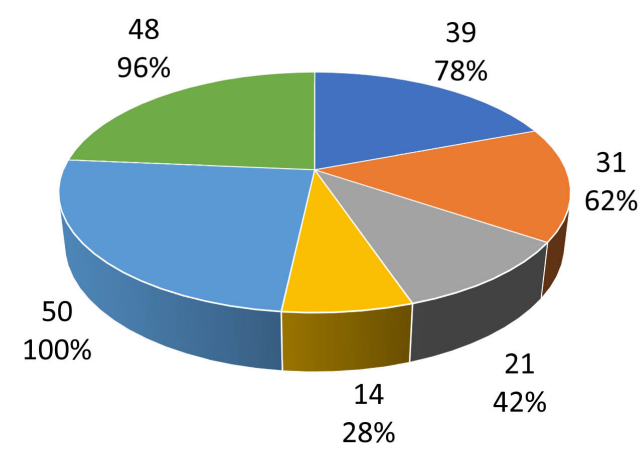

- Enacting/enforcement of relevant laws by state/Federal government

- Preservation according to the native laws/customs

- Avoid encroachment by building fences/buffers around protected areas

- Avoid bush burning

- Promote alternative source of firewood like gas cooker, cooking stove etc

- Others

Figure 9. Ways of achieving the protection of the forests. 


\section{Conclusions and Recommendations}

The state of forest reserve in the study area revealed that it has been disturbed or degraded by human activities as observed by the majority of sampled respondents for the study. The study also discovered that due to the high disturbance from human activities most of the common types of native plants and animals have become extinct and were last seen between 10 years and 30 years ago. The socio-economic and medicinal values derived from these forests plants by the local people usually involved such values as: Ethno-medicinal benefits, forest wood, income generation and source of food. Some of the ethno-medicinal values of the local plants names identified were Ayurveda used for treatment of tumour; Maprounnea used for the treatment of hypertension and Unani for malaria infections amongst others. According to [17], forests play significant roles in supporting the socio-economic livelihood of the people especially in the rural communities, which its measurements may vary from country to country depending on the level of development, social functions and traditions. [15] reported huge loss of genetic base or gene bank, decrease in biodiversity, deforestation, siltation of streams and loss of wildlife as consequences of human occupational activities within the Stubbs Creek Forest Reserve on the environment which means an automatic reduction in the socio-economic livelihood of the people.

Findings of the study further revealed that the size of the forests is actually reducing over time due to constant deforestation owing to human activities as majority of sampled respondents (96\%) indicated reduction in its size. The study also discovered that the Oil and Gas Installations from the Marginal Field Operators like the Universal Energy Resources Ltd, Frontier Ltd and Mobil Producing Nigeria Unlimited occupied a sizeable portion of the Stubbs Creek Forest Reserve as their activities are among the specific factors responsible for deforestation in the area. Similarly, the perception assessment also revealed that encroachment for settlement, overgrazing, fire incidents and increasing farming activities are other factors adding to the rate of deforestation of the forest reserve. The findings of the study corroborate with the findings of [9] [18] which reported that a larger chunk of Forest Reserve has been degraded due to human activities like farming, oil production, sand mining etc. Further expansion of such anthropogenic activities would mean more land shall be cleared which automatically will result to reduction in the benefits derived from the forest by the local people.

The benefits derived from the forests as indicated by the local people include; provision of food for domestic consumption, medicinal uses, tourism, source of income, source of firewood and timber, erosion control and flood protection, improved air quality and so on. In line with this, [19] emphasized that the contribution that effective forest actually leads to poverty reduction and increasing the livelihood resilience of the poor and local people cannot be overstated. In essence, the research revealed that the increasing activities of Oil and Gas com- 
panies, uncontrolled farming and other socio-economic activities from the inhabitants of the area mean further reduction in plant resources of the forest reserve. The human activities that contribute to forest degradation and reduction in size should be controlled by enacting and enforcement of relevant laws; educating and encouraging local participation on effective forest management practices as well as provision of alternative source of firewood all to enhance the conservation and preservation of the forest reserve.

\section{Conflicts of Interest}

The authors declare no conflicts of interest regarding the publication of this paper.

\section{References}

[1] Abu, M.A. and Adebisi, K.I. (2002) Economic Contribution of Moringa oieifera Plantation to Rural Livelihoods in Maradi Local Government Area of Niger Republic. Obeche Journal, 28, 142-146.

[2] Agbogidi, O.M. and Okonta, A.U. (2009) Biodiversity Conservation and Poverty Alleviation in the Niger Delat Are of Nigeria. Agriculturea Conspectus Scientificus, 71, 103-110.

[3] Aimufia, I.A. (2002) The Impact of Climate Change on Forest Resources. Proceedings of the 2 nd Biennial National Conference of the Forests and Forest Product Society of Nigeria. Federal University of Technology, Akure, Nigeria, 26-29 April 2010, 132-135.

[4] Etukudo, I. (2000) Forests: Our Divine Treasure. Dorand Publishers, Uyo, Nigeria.

[5] Faleyimu, O.I. and Akinyemi, M. (2014) Socio-Economic Assessment of Urban Forestry Respondents' Income in Okitipupa, Ondo State, Nigeria. Journal of Applied Science, Environment and Management, 18, 603-607.

https://doi.org/10.4314/jasem.v18i4.7

[6] Udo, E.S. (2001) The Position of Forestry in Akwa Ibom State. Proceedings of the 1 st Workshop of Forestry Association of Nigeria, Akwa Ibom State Branch in Collaboration with the Department of Forestry and Wildlife. University of Uyo, State Ministry of Environment and the UNDP, Akwa Ibom State held in Uyo, Akwa Ibom State, 10-11 April 2001, 31-43.

[7] Baptista, S.R. (2008) Metropolitan and Forest Recovery in Southern Brazil: A Multiscale Analysis of the Florianopolis City-Region, Santa Catarina State, 1970 to 2005. Ecology and Society, 13, 14.

file://C:/Users/u-nel systems/Downloads/ES-2008-2426.pdf

https://doi.org/10.5751/ES-02426-130205

[8] Ekpenyong R.E. (2015) An Assessment of Land Cover Change and Erosion Risk in Akwa Ibom State of Nigeria Using the Co-Ordination of Information on the Environment (CORINE) Methodology. Greener Journal of Physical Sciences, 3, 76-89.

[9] Akpan-Ebe, I.N. (2014) Reforesting the Tropical Rainforest in South-Eastern Nigeria. Nigerian Journal of Agriculture, Food and Environment, 10, 128-134.

[10] Ogar, D.A., Asuk, S.A. and Umanah, I.E. (2016) Forest Cover Change in Stubbs Creek Forest Reserve in Akwa Ibom State, Nigeria. Journal of Applied Tropical Agriculture, 21, 183-189.

[11] Protected Planet Report (2016) International Union for Conservation of Nature (IUCN) Global Protected Areas Programme, IUCN Headquaters, Rue Mauverney 28, 1196 Gland, Switzerland. https://www.iucn.org/theme/protected-areas 
[12] Koffi, U.S. (2015) Petroleum Activities, Wetland Utilization and Livelihood Changes in Southern Akwa Ibom State, Nigeria (2003-2015). Lund University, Sweden.

[13] Ukut, A.N., Akpan, U.S. and Udoh, B.T. (2014) Characterization and Classification of Soil in Steep Sided Hills and Sharped-Crested Ridges of Akwa Ibom State, Nigeria. Net Journal of Agricultural Science, 2, 50-57.

[14] Adava, G., Eze, L.C. and Dominic, E.U. (2017) Overview on the Emergence of Marginal Oil Fields in Nigeria and their Contributions to the Country's Oil Production. Nigeria Journal of Oil and Gas Technology, 2, 233.

[15] Essien, B.S. and Udoh, S.O. (2015) Human Occupational Activities in the Stubbs Creek Forest Reserves (scfr) of Akwa Ibom State: Impacts and Implications on Socio-Economic Environment. International Journal of Development Research, 5, 3880-3887.

[16] Population and Housing Census (2010) Federal Republic of Nigeria, Priority Table,Vol. 4, 22-34.

[17] Food and Agricultural Organization (FAO) (2005) Global Forest Resources Assessment 2005, Progress towards Sustainable Forest Management. Chapter 7: Socio-Economic Functions, 107-108.

[18] Ndoho, J.T., Umoren, V.E. and Adu, E. (2009) Spatial Analysis of Illegal Resource Extraction in Stubbs Creek Forest Reserve in Akwa Ibom State. Nigerian Journal of Agriculture, Food and Environment, 5, 72-78.

[19] Global Forest Resources Assessment (FRA) (2010) Special Study on Forestry, Poverty and Livelihoods. https://www.fao.org/3/i1757e/i1757e07.pdf 